\title{
Automated Teller Machine (ATM)- A "pathogen city" - A Surveillance Report from Locations in and around Madurai city, Tamil Nadu, India
}

\author{
Mabel Joshaline C. ${ }^{1}$, Subathra M. ${ }^{2}$, Shyamala M. ${ }^{1}$, Padma S. $^{2}$, Rekha $^{1}$ \\ ${ }^{1}$ Department of Microbiology, Sourashtra College, Madurai. 625004, Tamil Nadu, India \\ ${ }^{2}$ Department of Microbiology, Thiyagarajar College, Madurai. 625009, Tamil Nadu, India
}

Article Info

Article history:

Received Nov 17, 2013

Revised Jan 20, 2014

Accepted Feb 26, 2014

\section{Keyword:}

ATM

Pathogens

Surveillance

Madurai city

\begin{abstract}
ATM is used by millions of people in a day. It is meant to be a public utility device. Hence the microorganism's plays a major role in accommodating the safer place, ATM. Hence to this account an elaborate survey was taken for complete assessment of microbiology in and around Madurai city. Swabs were collected from each ATM screen, buttons, floor, users hand, exposure of plates and also extended the work in relation with microorganisms prevalent in ladies toilet the samples collected from ATM were plated in nutrient agar plates. The results showed the presence of increased bacterial count subsequently, most pathogens on characterization extended revealed the genus of the particular organism E-coli, Pseudomonas, Staphylococcus aures, Klebsiella, Micrococcus, Salmonella, Serratia and fungal species included Aspergillus sp, Mucor sp and Fusarium. Antibiogram study of bacteria also provides us information about the antibiotic resistance pattern of the bacterial isolates.
\end{abstract}

Copyright $(2014$ Institute of Advanced Engineering and Science. All rights reserved.

\section{Corresponding Author:}

Rekha,

Department of Microbiology,

Sourashtra College,

Madurai. 625004, Tamil Nadu, India.

Email: jesmabmary2512@gmail.com

\section{INTRODUCTION}

Atmospheric pollution is one of the most pressing problems of our age. This pollution has now reached an advance level those posses a potential threat to the health and well being of the population. Bacterial pathogens still play a considerable role in environment making a potential reservoir for bacterial pathogens since diverse pathogenic microorganisms and a large number of susceptible bacterial pathogen associated with a background rise in various types of indoor and outdoor environments. The increased risk frequency has risen in spreading the pathogenicsity from atmosphere where aerosols play a role in adhesion towards the surfaces. There's nothing quite like the pastime of cloud watching. We can spend hours watching these ethereal formations pass by. We can find shapes in them, try to imagine where they came from and where they are going and whether or not they are going to open up and douse us with precipitation. There exists another mental activity that we can undertake during this time: we can guess what germs are living deep inside these floating entities. The reservoir of any organism, which may be animate or inanimate objects, in the epidemiology of any bacterial disease is very important [1]. The pathogens live and or multiply in the reservoir on which their survival depends. Pathogens live on fomites. Many epidemiological studies have confirmed that many contaminated surfaces played a major role in the spread of infectious diseases [2],[3]. Most people do not realize that microbes are found on many common objects outdoors, in their offices, and even in their homes. Such objects include; playground equipments, ATM keyboards, kitchen sinks, office desks, computer keyboards, escalator handrails, elevator buttons and with the spread of supermarkets and hypermarkets the shopping carts handles. Dr. Richard Hastings, the Microbiologist for 
BioCote, a built-in antibacterial product coating, said, "'We were surprised by our results because the ATM machines were shown to be heavily contaminated with bacteria; to the same level as nearby public lavatories."Besides the ATM machines, even the public telephones are also a heavy source of contaminations and are considered to be the biggest threat. A large section of the adults is quite selective in using the public telephones because they are concerned about the dirt or bugs that they fear to be present. While public lavatories are on top, ATM machines are ranked tenth. The third place goes to the bus stops, especially the seats. Eighth place went to the train stations.

All of the latter objects are places that are most touched by the bare hands of people who are in various hygienic conditions. People believe that microbes are only present in research labs or in hospitals and clinics and thus they have a misleading feeling of security in other places. Lack of Knowledge about where germs prowl could be the cause of health problems. In fact $80 \%$ of infections are spread through hand contact with hands or other objects [4] used an invisible fluorescent tracer for artificial contamination of public surfaces, they found that contamination from outside surfaces was transferred to $86 \%$ of exposed individual's hands and $82 \%$ tracked the tracer to their home or personal belongings hours later. The viability of Grampositive and some Gram-negative organisms under various environmental conditions have been described [5]. Some microbes are infectious at very low doses and can survive for hours to weeks on nonporous surfaces, such as countertops and telephone hand pieces [4],[6] have demonstrated that health care workers' hands and mobile phones were contaminated with various types of Microorganisms. There is no restriction as to who has access to the facility, and no guidelines to ensure hygienic usage. But like all surfaces, microbial colonization of these metallic keypads are eminent, particularly so when there are no proper cleaning regimen in place for most of these facilities. Such colonization and their subsequent biofilm formation have been the theme of research by several investigators [7],[8].

Many factors have been shown to influence the bacteria transfers between surfaces, including the source and destination surface features, bacterial species involved, moisture levels, pressure and friction between the contact surfaces and inoculum size on surfaces (Chen et al., 2001; Rusin et al., 2002; Montville and Schaffner, 2003; Whitehead and Verran 2006 Kissiedu (2002) also showed that snacks eaten with the fingers can easily be cross contaminated by bacteria from the hands after handling dirty currency notes. It has also been shown that, microbes once attached to hands and to some surfaces may survive for a while and may be difficult to remove [9],[7]. Our study majorly depends upon the microbiological assessments on ATMs. Madurai was sub- divided into 4 zones to concise the sample collection as south, west, central, north. Complete profile of ATM were collected with references to the crowded and non crowded ATM. Swabs samples from ATM floor, ATM buttons ATM surface and ATM users hands were collected in and around Madurai district. This study was undertaken to measure, compare and characterize the aerobic microorganisms in computer keyboard.

\section{MATERIALS AND METHODS Study Design:}

ATMs were subdivided to concise the sample collection area wise Madurai north, south, east, and west and the assessment extended to part out crowded and non crowded ATMs. The samples were further divided into high touch surfaces like Screen, Button, Floor, Users Hands, and Plate Exposure.

Collection of Samples:

After complete review, swab samples were collected using sterile cotton swabs moistened with sterile saline. The cotton swabs were transferred immediately to the laboratory with one hour of collection to prevent dryness.

\section{Processing of Samples:}

All samples were collected processed in the research laboratory according to the standard microbiological methods under complete aseptic conditions. The swabs were inoculated on appropriate media and incubated at $37^{\circ} \mathrm{C}$ under aerobic conditions for $24-48 \mathrm{~h}$. To determine the types of microorganisms present, the remainder of the was sampled with a moistened sterile cotton swab, which was then placed into $4 \mathrm{ml}$ of peptone broth and incubated at $37^{\circ} \mathrm{C}$ for 48 hours. A variety of selective and differential microbiological media was used for presumptive identification of contaminating microorganisms. Characterization of samples:

Bacterial isolates were examined for colony morphology, pigmentation, cell shape and gram reaction as per the standard procedures given by [10],[11].

\section{Antibiotic sensitivity testing:}

The antibiotic sensitivity of the isolates (Pseudomonas, Staphylococcus, E-coli, Salmonella, Serratia, Klebsilla, Micrococcus, Fusarium, Mucor and Aspergillus) was determined by the disk diffusion method on Mueller-Hilton agar. The following antibiotics (Hi-Media) cotrimoxazole $(25 \mu \mathrm{g})$, Nalidixic acid $(30 \mu \mathrm{g})$, ciprofloxacin $(5 \mu \mathrm{g})$, ampicillin $(25 \mu \mathrm{g})$ gentamicin $(10 \mu \mathrm{g})$, tetracycline $(10 \mu \mathrm{g})$, Streptomycin $(10 \mu \mathrm{g})$,

IJPHS Vol. 3, No. 1, March 2014: $51-56$ 
Pencillin $(5 \mu \mathrm{g})$,Vacomycin $(5 \mu \mathrm{g})$ and chloramphenicol $(10 \mu \mathrm{g})$ were tested against the isolates. The inoculums were standardized by adjusting its density to equal the turbidity of a barium sulphate $\left(\mathrm{BaSO}_{4}\right)$ which is the $0.5 \mathrm{McFarland}$ turbidity standard, and incubated at $35^{\circ} \mathrm{C}$ for $18 \mathrm{~h}$. The diameter of the zone of clearance (including the diameter of the disk) was measured to the nearest whole millimeter and interpreted on the basis of CLSI guideline [12].

\section{RESULTS AND DISCUSSION}

The study briefly intimates the prevalence of organisms in ATMs. ATMs in Madurai where been listed and they were divided into four (north, south, west and central Madurai) and collection process were done. A total of 200 samples (ATM button (50), screen (50) and floor (50), users hands (20) from each location and direct plate exposure (20) in ATM, and from ladies toilets (10)) were collected,(Table 1). All the identified isolates along with the results from the various tests used in the characterizations are shown in Table $2 \& 3$. Majority of the isolates obtained were microorganisms considered to be pathogenic or probable pathogen from which microorganisms' nature and extent varied. Pathogenic fungi seem to be predominant. Subsequently to it Gram-negative bacilli (GNB) were more predominant than Gram-positive cocci (GPC).

Ten species of microorganisms: Staphylococcus, Serratia, Escherichia, Klebsiella, Pseudomonas and Salmonella, Micrococcus, Mucor Fusarium and Aspergillus was found to cross contaminate the fingers of user hands during cash-redraw simulation. ATM Screen, Floor as well as in button the results prevalently showed the presence of the Staphylococcus and fungal isolates such as Mucor, Penicillin and Aspergillus. The pathogenecity of most of the isolated species is well documented. Almost all serovars and species are identified to be pathogenic.ATM, Screen results showed that in crowded ATM the amount of bacterial and fungal count was increased, whereas in non crowded ATM the level conflicting and illustrated to be less. The results were tabulated in Table 1 and fig: 1. Next to screen Button, users hand swab and plate exposure revealed that high proportion of organisms were found to in crowded and least count in non crowded. ATM, Floor results were examined to reveal a report on predominant bacterial count in ATM (Crowded and Non Crowded) and thus depicting a increased bacterial existence (Table 1). Increased bacterial counts were documented in plate exposure on ladies toilet, and results of overnight exposure showed that fungal existence were found to be more when compared with 2 hrs and 6 hrs before and after cleaning. The existing bacterial colonies were found to be pathogenic and antibiotic resistance. (Table.2).

Table 1. Assessment of bacterial count from various ATM surfaces

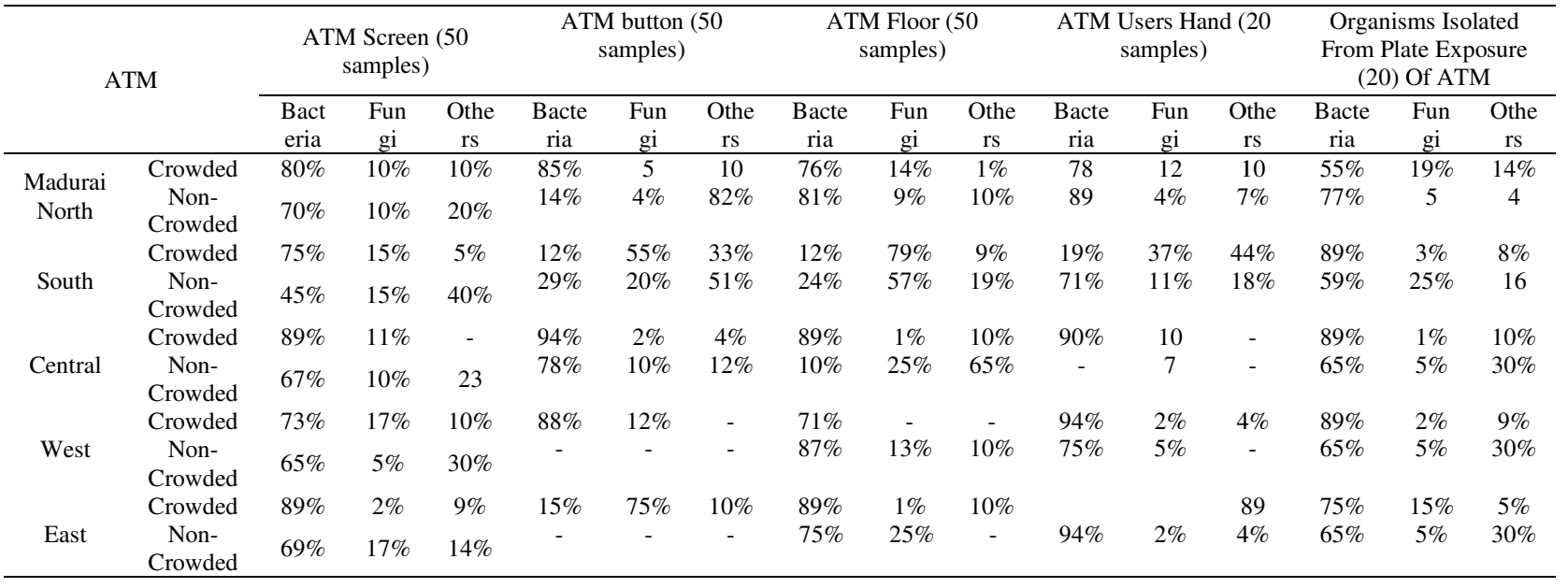

Table 2. Microorganisms prevalent in ladies toilets at various time intervals

\begin{tabular}{|c|c|c|c|c|}
\hline \multirow[b]{2}{*}{ Place of sample Collection } & \multicolumn{3}{|c|}{ Dominant Organisms (from 10 samples) } & \multirow{12}{*}{$\left.\begin{array}{l}600 \\
500 \\
400 \\
300 \\
200 \\
100 \\
0\end{array}\right]$} \\
\hline & $\begin{array}{l}\text { Bacteria } \\
\text { (NA) }\end{array}$ & $\begin{array}{l}\text { Fungi } \\
\text { (SDA) }\end{array}$ & $\begin{array}{l}\text { Others } \\
\text { (PDA) }\end{array}$ & \\
\hline Plate 1(Morning) & TNTC & 24 & 2 & \\
\hline Plate 2 (Evening) & 220 & 21 & 10 & \\
\hline Plate 3 (Before cleaning) & 120 & 12 & 4 & \\
\hline Plate 4 (Afternoon) & 100 & 11 & 12 & \\
\hline Plate 5(Morning) & TNTC & 25 & 11 & \\
\hline Plate 6 (After cleaning) & 75 & 4 & - & \\
\hline Plate 7 (Before cleaning) & 92 & - & - & \\
\hline Plate 8(Morning) & 88 & - & - & \\
\hline Plate 9 (overnight (18 hrs)) & TNTC & TNTC & - & \\
\hline Plate 10(Morning) & 41 & - & - & \\
\hline
\end{tabular}

ATM- A "Pathogen City" - A Sureillance Report from Locations In and Around Madurai (Mabel Joshaline) 
Table 3. Morphological characterization of isolates predominantly found in ATM and Ladies Toilet

\begin{tabular}{|c|c|c|c|c|c|c|c|c|}
\hline \multirow[t]{2}{*}{ S.No } & \multirow{2}{*}{$\frac{\text { Morphological }}{\text { characters }}$} & \multicolumn{7}{|c|}{ Organisms } \\
\hline & & Isolate 1 & Isolate 2 & Isolate 3 & Isolate 4 & Isolate 5 & Isolate 6 & Isolate 7 \\
\hline 1. & $\begin{array}{c}\text { Pigment } \\
\text { production }\end{array}$ & Green pigment & - & - & Yellow & $\begin{array}{l}\text { white, red } \\
\text { or Dark } \\
\text { pink }\end{array}$ & - & $\begin{array}{l}\text { Golden } \\
\text { Yellow to } \\
\text { orange }\end{array}$ \\
\hline 2. & Blood agar & $\begin{array}{l}\text { B- haemolytic } \\
\text { with musty } \\
\text { odour }\end{array}$ & $\begin{array}{c}\beta \\
\text { Hemolytic } \\
\text { colonies }\end{array}$ & - & $\begin{array}{c}\text { Non- } \\
\text { haemolytic, it } \\
\text { forms cubical } \\
\text { packets usually } \\
\text { produced } \\
\text { colonies with a } \\
\text { granular } \\
\text { surface and } \\
\text { matt } \\
\text { appearance }\end{array}$ & - & - & $\begin{array}{c}\beta \\
\text { Hemolytic } \\
\text { colonies }\end{array}$ \\
\hline 3. & $\begin{array}{c}\text { Maconkey } \\
\text { agar }\end{array}$ & $\begin{array}{l}\text { Lactose } \\
\text { positive }\end{array}$ & $\begin{array}{c}\text { Translucent } \\
\text { colourless } \\
\text { colonies }\end{array}$ & $\begin{array}{c}\text { Bright pink } \\
\text { colour } \\
\text { colonies }\end{array}$ & $\begin{array}{l}\text { Opaque and } \\
\text { round }\end{array}$ & - & $\begin{array}{c}\text { White } \\
\text { colourless } \\
\text { colonies }\end{array}$ & $\begin{array}{l}\text { Small } \\
\text { pink } \\
\text { colour } \\
\text { colonies }\end{array}$ \\
\hline 4. & Broth medium & $\begin{array}{l}\text { Thick pellicle } \\
\text { dense turbidity } \\
\text { and heavy } \\
\text { sediment on } \\
\text { the bottom of } \\
\text { the tube }\end{array}$ & - & $\begin{array}{c}\text { General } \\
\text { turbidity\& } \\
\text { Heavy } \\
\text { deposits } \\
\text { which } \\
\text { disperses } \\
\text { completely on } \\
\text { shaking }\end{array}$ & $\begin{array}{l}\text { Uniform } \\
\text { turbidity }\end{array}$ & - & - & $\begin{array}{l}\text { Uniform } \\
\text { turbidity }\end{array}$ \\
\hline 5. & Gram reaction & Gram negative & $\begin{array}{c}\text { Gram } \\
\text { negative }\end{array}$ & $\begin{array}{c}\text { Gram } \\
\text { negative }\end{array}$ & Gram positive & $\begin{array}{c}\text { Gram } \\
\text { negative }\end{array}$ & Negative & $\begin{array}{c}\text { Gram } \\
\text { Positive }\end{array}$ \\
\hline 6. & Motility & Motile & Motile & Motile & Non-Motile & Motile & Negative & Negative \\
\hline 7. & Shape & $\begin{array}{l}\text { Straight or } \\
\text { slightly curved } \\
\text { rods }\end{array}$ & $\begin{array}{l}\text { Straight } \\
\text { rods }\end{array}$ & rods & $\begin{array}{l}\text { Cocci in } \\
\text { tetrads, pairs }\end{array}$ & $\begin{array}{l}\text { Red } \\
\text { colour } \\
\text { mucoid } \\
\text { colony }\end{array}$ & Rod & cocci \\
\hline 8. & Spore & Negative & Negative & Negative & Negative & Negative & Positive & Negative \\
\hline
\end{tabular}

Table 4. Biochemical characterization of isolates predominantly found in ATM and Ladies Toilet

\begin{tabular}{|c|c|c|c|c|c|c|c|c|}
\hline \multirow{2}{*}{ S.No } & \multirow{2}{*}{$\frac{\text { Biochemical }}{\text { characters }}$} & \multicolumn{7}{|c|}{ Organisms } \\
\hline & & Isolate 1 & Isolate 2 & Isolate 3 & Isolate 4 & Isolate 5 & Isolate 6 & Isolate 7 \\
\hline 1. & Catalase & Positive & Positive & Positive & Positive & Positive & Positive & Positive \\
\hline 2. & Oxidase & Positive & Negative & Negative & Positive & Positive & - & Negative \\
\hline 3. & $\begin{array}{l}\text { Indole } \\
\text { production }\end{array}$ & Negative & Negative & Positive & Negative & Negative & Negative & Negative \\
\hline 4. & Methyl red & Negative & Positive & Positive & Negative & - & Negative & Positive \\
\hline 5. & $\begin{array}{l}\text { Voges- } \\
\text { Prosakauer }\end{array}$ & Negative & Negative & Negative & Negative & Positive & Positive & Positive \\
\hline 6. & Citrate & Positive & Positive & Negative & Negative & Positive & Positive & \\
\hline 7. & Urease & Positive & Positive & Negative & Positive & Positive & Positive & Positive \\
\hline 8. & $\begin{array}{c}\text { Starch } \\
\text { hydrolysis }\end{array}$ & Negative & - & Positive & Negative & Negative & Negative & Negative \\
\hline 9. & $\begin{array}{l}\text { Nitrate } \\
\text { reduction }\end{array}$ & Positive & - & Positive & Negative & Positive & - & Positive \\
\hline 10. & $\begin{array}{l}\text { Glucose } \\
\text { utilization }\end{array}$ & Positive & Positive & Positive & Positive & $\begin{array}{l}\text { Positive } \\
\text { /Acid gas } \\
\text { production }\end{array}$ & Positive & Positive \\
\hline 11. & $\begin{array}{l}\text { Lactose } \\
\text { utilization }\end{array}$ & Negative & - & Positive & Negative & Negative & Positive & Positive \\
\hline 12. & Coagulase & Negative & - & Negative & Negative & - & - & Positive \\
\hline 13. & Gelatin & Positive & - & Negative & Negative & - & - & Positive \\
\hline 14. & $\mathrm{H}_{2} \mathrm{~S}$ & Negative & Positive & Negative & Negative & Negative & Positive & Negative \\
\hline 15. & TSI & $\begin{array}{c}\text { Alkaline } \\
\text { slant/ neutral } \\
\text { butt }\end{array}$ & - & $\begin{array}{l}\text { Acid butt/ } \\
\text { acid slant }\end{array}$ & $\begin{array}{c}\text { Alkaline } \\
\text { slant/ alkaline } \\
\text { butt }\end{array}$ & - & - & - \\
\hline 16. & $\begin{array}{c}\text { Genus } \\
\text { conformed as }\end{array}$ & Pseudomonas & Salmonella & E-coli & Micrococcus & Serratia & Klebsiella & Staphylococcus \\
\hline
\end{tabular}

IJPHS Vol. 3, No. 1, March 2014: $51-56$ 
Table 5. Antibiogram profile of the bacterial isolates

\begin{tabular}{|c|c|c|c|c|c|c|c|c|}
\hline \multirow{2}{*}{ S. No } & \multirow{2}{*}{ Antibiotics } & \multicolumn{7}{|c|}{ Zone of inhibition } \\
\hline & & 1 & 2 & 3 & 4 & 5 & 6 & 7 \\
\hline 1 & Amikacin & $\mathbf{R}$ & $\mathbf{R}$ & $\mathbf{R}$ & NZ & $\mathbf{R}$ & $\mathbf{R}$ & $\mathbf{R}$ \\
\hline 2 & Ampicillin & $\mathbf{R}$ & $\mathbf{R}$ & $\mathbf{R}$ & NZ & $\mathbf{R}$ & $\mathbf{R}$ & $\mathbf{R}$ \\
\hline 3 & Chloramphenicol & $\mathbf{R}$ & $\mathbf{R}$ & $\mathbf{R}$ & NZ & $\mathbf{R}$ & $\mathbf{R}$ & $\mathbf{R}$ \\
\hline 4 & Co-trimaxazole & $\mathbf{R}$ & NZ & $\mathbf{R}$ & $\mathbf{R}$ & $\mathbf{R}$ & $\mathbf{R}$ & $\mathbf{R}$ \\
\hline 5 & Nalidixic acid & $\mathbf{R}$ & $\mathbf{R}$ & $\mathbf{R}$ & $\mathbf{R}$ & $\mathbf{R}$ & $\mathbf{R}$ & $\mathbf{R}$ \\
\hline 6 & Penicillin & $\mathbf{R}$ & $\mathbf{R}$ & NZ & $\mathbf{R}$ & $\mathbf{R}$ & $\mathbf{R}$ & $\mathbf{R}$ \\
\hline 7 & Streptomycin & $\mathbf{R}$ & $\mathbf{R}$ & NZ & $\mathbf{R}$ & $\mathbf{R}$ & $\mathbf{R}$ & $\mathbf{R}$ \\
\hline 8 & Cefixime & NZ & NZ & $\mathbf{R}$ & $\mathbf{R}$ & $\mathbf{R}$ & $\mathbf{R}$ & $\mathbf{R}$ \\
\hline 9 & Bacitracin & NZ & NZ & $\mathbf{R}$ & $\mathbf{R}$ & $\mathbf{R}$ & $\mathbf{R}$ & $\mathbf{R}$ \\
\hline 10 & Ofloxacin & NZ & $\mathbf{R}$ & $\mathbf{R}$ & NZ & $\mathbf{R}$ & $\mathbf{R}$ & $\mathbf{R}$ \\
\hline
\end{tabular}

Discussion:

Computer keyboards are one of the most commonly touched and shared surfaces today. By inference, anytime a keyboard is shared among two or more people, it becomes a risk for the spread of infection [13]. Thus, keyboards have become reservoirs for pathogens especially in hospitals and schools [14].

As reported by [15],[16] soiling is an important factor in preserving viability of bacteria on hard surfaces. Thus dirty surfaces would harbor more bacteria than clean ones. This makes the process of dusting and removal of soil and dirt by simple cleaning procedures of paramount influence on the reduction of surface contamination. Although drying plays an important part in maintenance of hygiene on surfaces and other environments, drying per se cannot be relied upon to prevent transfer of infection from laminate surfaces due to the resistance of some microbes to that measure [17].

A total of 100 samples (ATM button (20), screen (20) and floor (20), users hands (10) from each location and direct plate exposure (20) in ATM, and from ladies toilets (10)) were collected,

Ten species of microorganisms: Staphylococcus, Serratia, Escherichia, Klebsiella, Pseudomonas and Salmonella, Micrococcus, Mucor Penicillin and Aspergillus was found to cross contaminate the fingers of user hands during cash-redraw simulation,.(Table.9\&10).

Though the counts of these organisms were not determined on the surfaces, the health significance of the results is nonetheless clear, especially as it has been documented that even low levels of Salmonella spp. and some Escherichia coli strains can easily be transferred from the fingers to food surfaces [18], which lead to acute ailments [19]. Species of Staphylococcus were the most commonly isolated on all three surfaces. Salmonella spp. Have been found to survive on dry surfaces for long periods, making its presence significant [20]. E. coli serovars, especially the enteropathogenic E. coli O157: H7, has been implicated in major food borne disease outbreaks and infections, mainly from eating contaminated meat [19]. Listeria monocytogenes, Bacillus cereus, Staphylococcus aureus, Klebsiella pneumoniae, Enterobacter spp. And Pseudomonas aeruginosa are all well documented for their high pathogenicity, causing even death in some major outbreaks and infections [19],[21],[22]. Other microbes isolated such Micrococcus, Alcaligenes, Aeromonas and Streptococcus spp. are known opportunistic pathogens in infections and food spoilers [21],[23].

Total of ten standard antibiotics were used with the predominant isolates. The results showed that organisms showed mostly resistant. This resistance was revealed by the presence R-plasmid. The occurrence of antibiotics in natural environments may favour the development and spread of antibiotic resistance. From an environmental health perspective, the selective pressure that antibiotic pollution may exert on bacteria of clinical importance is of particular concern. Several clinically relevant bacteria, such as E. coli and the enterococci, for example, occur and are able to grow in different environments [24], where in the presence of environmental concentrations of antibiotics they may face a selective pressure leading to a gradual increase in the prevalence of resistance.

\section{REFERENCES}

[1] Daniel, T., Haydon, Cleaveland, S., Taylor, L.H. and Karen, L.M. "Identifying reservoirs of infection", J. Microbial. BioTech Res. Pp. 213-234, 2002.

[2] Hendley, J. O., Wenzel, R. P. and Gwaltney, J. M. J. “Trasnsmission of rhinovirus colds by self-inoculation”, New. Eng. J. Med. Vol. 288. Pp. 1361-1664, 1997.

[3] Noble, J. Text book of primary care medicine. 3rd Edition. St Louis, Mo: Mosby. Pp. 8, 2001.

[4] Reynolds KA, Watt PM, Boone SA, Gerba CP. "Occurrence of bacteria and biochemical markers on public surfaces”, Int. J. Environ. Health Res., Vol. 15. Pp. 225-234, 2005.

[5] Noskin GA, Stosor V, Cooper I, Peterson LR. "Recovery of vancomycin-resistant enterococci on fingertips and environmental surfaces", Infect. Control Hosp. Epidemiol., Vol. 16. Pp. 577-581, 1995.

ATM- A "Pathogen City" - A Sureillance Report from Locations In and Around Madurai (Mabel Joshaline) 
[6] F. Ulger, S. Esen, A. Dilek, K. Yanik, M. Gunaydin and H. Leblebicioglu, “Are We Aware How Contaminated Our Mobile Phones with Nosocomial Pathogens?" Annals of Clinical Microbiology and Antimicrobials, Vol/No: 8(7). Pp. 7, 2009. doi:10.1186/1476-0711-8-7

[7] Hood, S.K. and E.A. Zottola. "Adherence to stainless steel by foodborne microorganisms during growth in model food systems", Int. J. Food Microbiol., Vol. 37. Pp. 145-153, 1997. DOI: 10.1016/S0168- 1605(97)00071-8

[8] Sharma, M. and S.K. Anand. "Biofilms evaluation as an essential component of HACCP for food/dairy processing industry-a case", Food Control, Vol. 13. Pp. 469- 477, 2002. DOI: 10.1016/S0956-7135(01)00068-8.

[9] Filho PPG, Stumpf M, Cardoso A. "Survival of gram positive bacteria, gram negative bacteria artificially applied to hands", Journal of Clinical Microbiology, Vol. 23. Pp. 552- 553, 1987.

[10] Anon Van Belkum A, Verbrugh H. "Nasal carriage of Staphylococcus aureus: epidemiology, underlying mechanisms, and associated risks", Clin. Microbiol. Rev., Vol. 10. Pp. 505-550, 1957.

[11] Bartholomew and Mittewer. "Guideline for Hand in health care settlings: recommendations of healthcare infection control practices advisory committee and HICPAC/SHEA/APIC/IDSA hand hygiene task force", Infect. Control hospital epidemiol., Vol. 23. Pp. 3-40, 2008.

[12] Clinical Laboratory Standard Institute. Performance standards for antimicrobial susceptibility testing. Fifteen informational supplement; M100-S15. Wayne, PA: CLSI; 2005

[13] Marsden R A Solid-Surfaced Infection Control Computer Keyboard. www.cleankeys.nl/whitepaper.pdf. Pp. 1-5, 2009.

[14] Diggs R, Diallo A, Kan H, Glymph C, Furness BW, Chai SJ. Norovirus outbreak in an elementary school-District of Columbia, February 2007. Centers for Disease Control and Prevention: Morb.Mortal. Wkly. Rep., 51: 1340$1343,2008$.

[15] Lowbury EJL, Fox J. "The influence of atmospheric drying on the survival of wound flora", J. Hyg., Vol. 51. Pp. 203-214, 1953.

[16] Rathmachers B, Borneff M. Development of a new test method for surface disinfection procedures IV: Natural drying rates of microorganisms and their modification by environmental factors, 1977.

[17] Scott E, Bloomfield SF. "The survival and transfer of microbial contamination via cloths, hands and utensils", $J$. Appl. Microbiol., Vol. 68. Pp. 271-278, 2008.

[18] Rusin P, Maxwell S, Gerba C. "Comparative surface-to-hand and fingertip-to-mouth transfer efficiency of grampositive bacteria, gramnegative bacteria, and phage", J. Appl. Microbiol., Vol. 93. Pp. 585-592, 2002.

[19] Anonymous. Global ATM clock. Automatic teller machine industry association (ATMIA), 2011. (http://www.atmia.com/mig/globalatmclock/).

[20] Humphrey TJ, Martin KW, Whitehead A. "Contamination of hands and work surfaces with Salmonella enteritidis PT4 during the preparation of egg dishes", Epidemiology and Infection, Vol. 113. Pp. 403-409, 1994.

[21] FDA. Foodborne pathogenic microorganisms and natural toxins handbook - The bad bug book. Food and Drugs Administration of the United States, Silver Springs, MD, USA, 2002. Accessed 24 May 2011, (http://www.fda.gov/Food/FoodSafety/FoodborneIllness/FoodborneIllnessFoodbornePathogensNaturalToxins/BadB ugBook/default.htm).

[22] Mead PS, Slutcsker L, Dietz V, McCaig LF, Bresee JS, Shapiro C, Griffin PM, Tauxe RV. "Food-Related Illness and Death in the United States”, Emerging Infectious Diseases, Vol/Issue: 5(5). Pp. 607-625, 1999.

[23] Kaluski DN, Barak E, Kaufman Z, Valinsky L, Marva E, Korenman Z, Goronitzki Z, Yishai R, Koltai, D., Leventhal, A., Levin, S., Havkin, O. Green MS. "A large food-borne outbreak of group A streptococcal pharyngitis in an industrial plant: potential for deliberate contamination", Israel Medical Association Journal, Vol. 8. Pp. 618621,2006

[24] Topp Brayton P, Herrington D, Tall B, Huq A, Levin M.M. "An environmental health perspective, the selective pressure that antibiotic pollution may exert on bacteria of clinical importance is of particular concern", J.Appl Microbiol., Vol. 93. Pp. 585-592, 2003.

IJPHS Vol. 3, No. 1, March 2014: $51-56$ 